\title{
Management of Student Elementary School in Java Island Indonesia
}

\author{
Mustiningsih \\ Department of Educational Administration, Faculty of Education, State University of Malang, Indonesia \\ mustiningsih.apfipum@yahoo.com
}

\begin{abstract}
Student are the subject of education in school. School success can be measured from the achievement of the learners. Management of student in elementary school (sekolah dasar / SD) is a way of students ranging from acceptance to the release of students in elementary school. The purpose of this research is to describe the implementation of the student management of elementary school in Java. This research uses quantitative approach of descriptive type. The research population was all elementary school principals in Java. The sampling technique used is purposive sampling. The research sample were 3 provinces, 6 districts / cities, and 18 head master of elementary schools. The results showed that the student management of elementary school on the island of Java was included in a very good qualification. Of the 6 indicators of elementary school student management Java is in very good qualifications.
\end{abstract}

Keywords: management of student, student, elementary school

\section{INTRODUCTION}

Student management is important because students are the subject and object learn transformation the attitude, knowledge and skills in school. The success in the implementation of education depends on the development of physical potential, intellectual intelligence, social, emotional and psychological learners. Jump (2006) provides a common concept development program. The basic assumptions that guide the student development movement: (1) each student is a different individual with unique needs; (2) the entire student environment must be taken into account and used for education; and (3) students have personal responsibility to get education.

Basic assumptions help learners to the development: (1) individual learners, individually have different and unique needs; (2) each learner has a different environment and is used for education; and (3) each learner has responsibility for his / her education. Allen (1986) states that why are there any successful learners who are not in school? That students come from diverse backgrounds, some with a harsh cultural background or racist background, conflict of causes, while others do not. All that happens to learners in education. It is necessary to arrange learners in order to have equal opportunity to obtain education and can develop optimally their potential.

The definition of learners in Undang-undang Sistem Pendidikan Nasional Nomor 20 Tahun 2003 regarding National Education System and Peraturan Pemerintah Number 19 Tahun 2005 on National Education Standards that has been amended by Government Regulation Number 32 Year 2013 on Amendment to Government Regulation Number 19 Year 2005 regarding National Education Standard, community members who seek to develop their own potential through the learning process available on a particular path, level, and type of education. According Arikunto (1986) whether learners are anyone who is the object of students in an educational institution.

Student management is the process of managing all matters relating to learners, school coaching starting from the planning of acceptance of learners, coaching during learners are in school, until the learners finish their education through an atmosphere conducive to the process of effective teaching and learning process
(Mantja, 2007). Sutjipto and Mukti (2009) states that the student management is a process of managing all matters relating to learners in a school ranging from planning, acceptance of learners, coaching conducted during the students were in school, until the students complete education in schools through learning that is conducive and constructive to the process of effective learning.

Another suggestion is that the student management is the setting up of learners in a powerful school that can help all staff and the community to understand the progress of a school (Saheran, 1985; Mulyasa, 2004). Knezevich (1984) defines students management or student administration personnel as a service that focuses on the setting, supervision and service of learners in the classroom and beyond the classroom such as: introduction, registration, individual services such as the development of the overall ability, interests, interests until students mature at school.

The purpose of student management is to organize the activities of learners to support the teaching and learning process in schools in the purpose of school and optimal educational goals (Directorate of Primary Education, 2013). Imron (2011) mentions the following objectives of the students management in particular: (1) improving the knowledge, skills, and psychomotor of learners; (2) channeling and developing the general skills (intelligence), talents and interests of learners; (3) channeling aspirations, hope and meet the needs of learners; and (4) with the fulfillment of all the above expected learners can achieve happiness and welfare of life that can further learn well and achieved their goals.

Based on some opinions above it can be concluded that the purpose of student management is to organize activities in the field of learners so that the learning process carried out in a school can run smoothly, orderly and regular so as to contribute to the achievement of school goals and educational objectives whole. Through student management also, the school is expected to be able to arrange all the activities of learners who basically have different conditions from each other. Differences in the condition of these learners, among others, in terms of physical conditions, intellectual ability, social economy, and interest. 
The function of student management is a means for learners to develop themselves as optimally as possible, whether individual, social, aspirations, needs and other potential (Directorate of Primary Education, 2013). Another expert states that the student management function in general is as a vehicle for learners to develop themselves as optimally as possible, both with regard to aspects of individuality, social aspect, aspiration aspect, needs aspect and other students' potential aspects (Imron, 1994). While the function of student management in particular, among others: (1) the function associated with the development of learners of individuality, is that they can develop the potential of individuality without much hampered. These innate potentials include: general ability of intelligence, special abilities (talents) and other abilities; (2) functions related to the development of the social aspects of learners, is that learners can socialize with peers with parents and family, with the environment; (3) functions related to channeling the aspirations and expectations of learners is that learners distributed hobbies, pleasures and interests; and (4) functions related to the fulfillment of the needs and welfare of learners is that learners prosperous in his life.

The implementation of student management is based on several principles: (1) student management is seen as part of the overall school management; (2) all forms of student management should be aimed at carrying out educational missions and for educating learners; (3) student management activities should be conducted to bring learners to diverse backgrounds and differences; (4) the activities of the learners should be seen as an effort to regulate learners guidance; (5) student management activities should encourage and enhance the independence of learners; (6) student management must work for the life of the learner, both at school in the future; and (7) implementation of student prototypes recognizes the characteristics of learners, including intellectual, interests, talents, personal needs, experience, and physical circumstances (Directorate of Primary Education, 2013).

Imron (2011) reveals that there are six principles in the student management, namely: (1) student management is seen as part of the overall school management, therefore must have the same goals or support the overall goal of school management; (2) all forms of student management activities should develop an educational mission in order to educate the learners; (3) student activities should be strived to bring together learners who have diverse backgrounds and have many differences; (4) student management activities should be seen as an effort to guide the students, because in guiding there must be availability of the mentored, ie the learners themselves; (5) the students management activities of the should encourage and encourage the independence of learners; and (6) what is given to learners and which is always pursued by the management activities of the learners should be functional for the life of learners in the school in the future moreover.

Scope in general proposed by Rugaiyah \& Sismiati (2011) and Arikunto \& Yuliana (2008) which is a learner participant is learning activity of learner begins with acceptance of new student, registration, selection, acceptance or placement. Once the learners are accepted, the next stage is to provide disciplinary coaching, ongoing activities in the school environment as well as outside the school. Activity of talent and interest development through extracurricular activities and other activities. Talent guidance is done until the learner graduated from the school, the final stage of the relationship with the alumni. So it can be concluded that the student management is all things related to learners in a school ranging from planning, acceptance of learners, coaching done during the students are in school, until the students complete education at school.

The general purpose of this research is to describe the implementation of the student management of elementary school in Java. Specifically, the aim of the research are to: (1) describe the students management of elementary school in Java based on: division of West Java, Central Java and East Java; and district and city areas; and (2) describe each indicator student management elementary school in island of Java, including: steps for new student admission (Penerimaan Peserta Didik Baru / PPDB); extracurricular activities; consideration of extracurricular activities; discipline of learners; gifted student services; and documenting evidence of student management activities.

\section{METHODS}

This research uses quantitative approach of descriptive type. The use of this approach is intended to obtain an accurate picture of students' management descriptions. The population of this research is all elementary school in Java which is divided into 6 provincial areas namely: DKI Jakarta, West Java (Jabar), Banten, Central Java (Jateng), Special Region of Yogyakarta (DIY), and East Java (Jatim). Because the amount and the area of Java Island is too large, then taken a sample or representative by technique area purposive sampling. The selected areas are West Java, Central Java and East Java Provinces. This area is chosen purposively because it is considered to represent the 6 (six) provinces in Java. West Java Province represents the provinces of Jakarta Capital City Special Region (DKI), West Java, and Banten. Central Java province represents the province of Central Java itself and the Special Region of Yogyakarta (DIY). The province of East Java stands alone because it is based on the size of its territory, in proportion to the provinces of Central Java and West Java, and no other provinces exist within its geographical area.

Purposive sampling is also used to determine: (1) The number of samples taken for each province, is 1 (one) district and 1 (city), (2) Number of samples for each district / city is 3 schools. In order to determine the school used as research sample used random technique. Thus, the sampling technique overall is area purposive random sampling. Based on sampling technique criteria, sampling is done by following steps: (1) determining sample of research 3 (three) province that is province of West Java, Central Java and East 
Java with purposive sampling; (2) determining the district / city target of each province, i.e. 3 (three) schools in the city area and 3 schools from the district with purposive sampling; and (3) establish 3 sample schools from each regency / city, resulting in 18 (3 provinces $\mathrm{x} 2$ district / city 3 schools) SD with random sampling. The sample of this research can be seen in Table 1.

Table 1

Research Samples by Province and District / City

\begin{tabular}{clll}
\hline No & Province & District and City & School Name \\
\hline 1 & West Java & Bandung City & SDN Asmi \\
2 & West Java & Bandung City & SDN Andir Kidul \\
3 & West Java & Bandung City & SDN Sejahtera 4 \\
4 & West Java & Sumedang District & SDN Tegalkalong 1 \\
5 & West Java & Sumedang District & SDN Pasanggrahan 1 \\
6 & West Java & Sumedang District & SDN Gudang I \\
7 & Central Java & Semarang City & SDN Kepunden \\
8 & Central Java & Semarang City & SD Hj. Isriati Baiturrahman \\
9 & Central Java & Semarang City & SDN Pedurungan Tengah 02 \\
10 & Central Java & Batang District & SDN Sawahjoho 01 \\
11 & Central Java & Batang District & SDN Tegalsari 02 \\
12 & Central Java & Batang District & SDN Wonokerso 01 \\
13 & East Jawa & Malang City & SD Insan Amanah \\
14 & East Jawa & Malang City & SDN Purwantoro I \\
15 & East Jawa & Malang City & SDN Pandan Wangi 1 \\
16 & East Jawa & Blitar District & SDN Kademangan 01 \\
17 & East Jawa & Blitar District & SDN Kademangan 05 \\
18 & East Jawa & Blitar District & SDN Kanigoro 03 \\
\hline
\end{tabular}

This instrument research uses closed questionnaire. Instruments are prepared based on the description of indicator research and stated in the form of statement that is:

1. Schools in implementing the acceptance of new learners using the steps that must be done in the procedure of acceptance of new learners include: formation of the committee; new student determination meeting (requirements, capacity, number of candidates received, acceptance criteria, and selection system); registration announcement; registration; determination of newly accepted learners; announcement of newly received students; re-listing of newly received learners; and class divisions.

2. Schools organize extracurricular activities. Extracurricular activities that can be held by schools include: scout; health services (School Health Efforts / UKS); sports; religious; and art culture / skills.

3. Arrangement of extracurricular activities shall be conducted with certain considerations. Extracurricular activities are organized through four considerations, namely: availability of educators; curriculum / program; the scope of facilities and infrastructure / tools / facilities / materials; and local environmental conditions / local culture.

4. School develops, implements and enforces students' discipline programs using various steps: schools make rules for students; school rules / rules are socialized to learners, parents / guardians of learners, and the school community; all the citizens of the school do a positive habit to set an example to learners; other principals, teachers, and school staff provide control; and give rewards and punishment.

5. Schools provide services to gifted learners and or are privileged to participate in a number of activities (e.g. peer tutors, MIPA Olympics, achievement sports) through a number of steps: create a program; implementing the program; facilitate the program; overseeing the execution; and follow-up.

6. Schools make documents / books evidence of student management activities include: form of new student enrollment form; list book of class candidates; book list of new class learners; master books learners; book klapper; book number of students by class of origin, gender, and date of late / age; books and formatting of the procedures of learners; daily presentation board of learners; recapitulation of daily presentation of learners; monthly student presentation book presentation; book list of class increases; book recapitulation of class increase; format of school transfer application letter; format of school transfer letter; mutation book of learners for 1 semester; list of school / end exam candidates; format of final exam signs; book of exhibit present final examination; the list book of UAS participants and their achievements; student recapitulation book up class and successful final test; continuing alumni list books and not continue to junior high school / sederajad; book of guidance and counseling program; and BP book / case settlement learners.

The scoring criteria use the following provisions:

- Rating A has a score of : :4

- Rating B has a score of : 3

- Rating $\mathrm{C}$ has a score of $: 2$

- Rating D has a scores : 1

The collected data were analyzed by descriptive analysis technique to find percentage and average. The scoring results are interpreted based on existing guidelines for subsequent discussion. The interpretation guidelines for determining the student management descriptions are presented in Table 2. 
Table 2

Data Interpretation Guidelines

\begin{tabular}{ccc}
\hline No & Range Score & Qualifying \\
\hline 1 & $86-100$ & Very good \\
2 & $71-85$ & Good \\
3 & $56-70$ & Enough \\
4 & $36-55$ & Less \\
5 & $1-35$ & Very Less \\
\hline
\end{tabular}

\section{RESULTS AND DISCUSSION}

The data exposure includes data descriptions of: (1) student management in elementary school of Java (Table 3); (2) student management in elementary school of Java Island, from highest to lowest score (Table 4); and (3) student management in elementary school of Java Island by city and district (Table 5).
Table 3 describes student management data on elementary school in Java the average scores on overall student management of elementary school in Java, average score of student management based on province of elementary school in Java, and average score of each aspect / indicator element students management of elementary school in Java.

Table 3

Data Description of Student Management in Elementary School Java Island

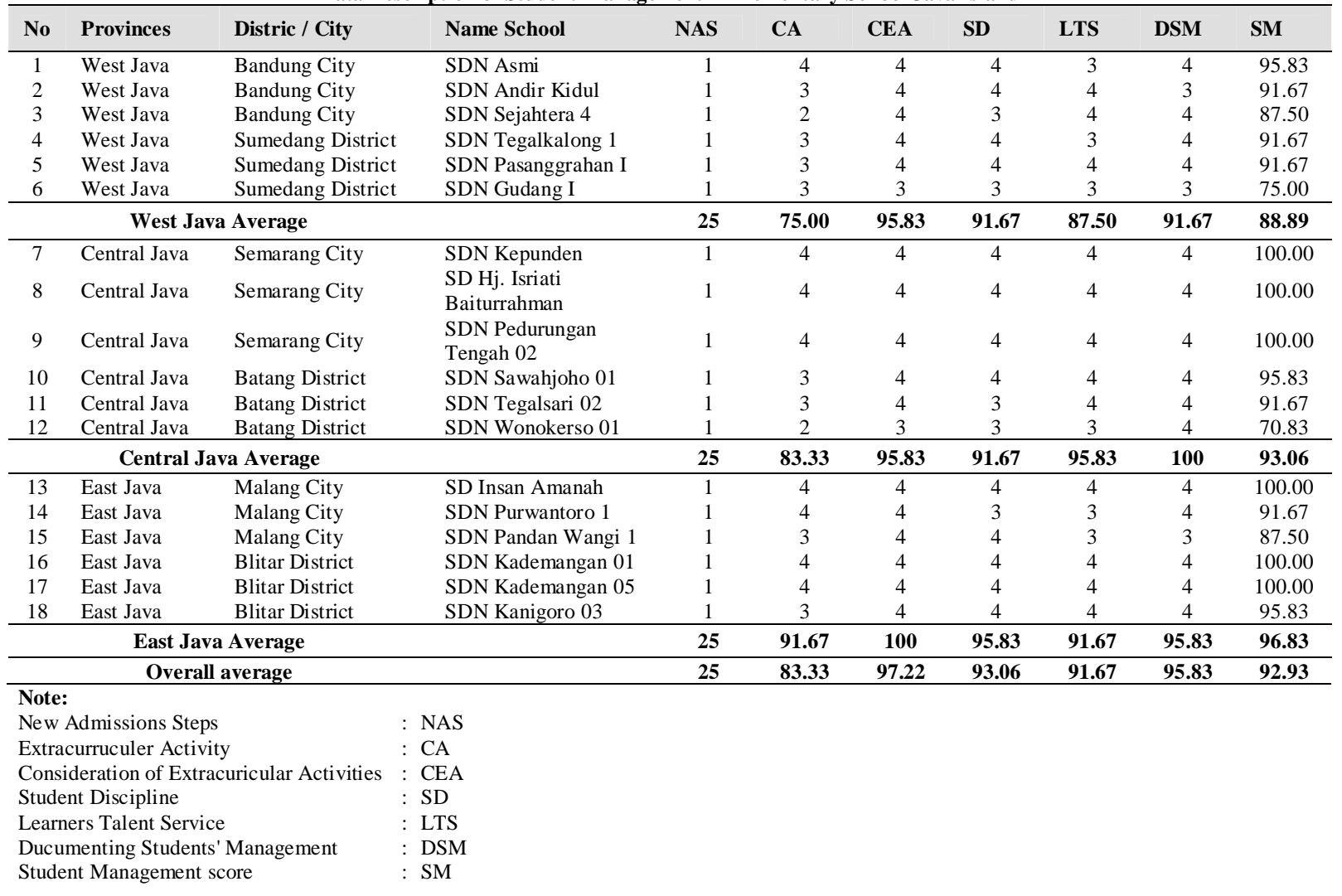

Based on Table 3 it can be concluded that:

1. The average score of overall student management of elementary school in Java is 92, 93 including in excellent qualifications.

2. Student management of education school in the island of Java which is above the overall average score is 9. At least from West Java as much as 1 elementary school, while from Central Java 4 elementary school and East Jawa 4 elementary school. Complete as follows: SDN Asmi (Bandung City, West Java); SDN Kepunden (Semarang City, Central Java); $\mathrm{SD} \mathrm{Hj}$. Isriati Baiturrohman (Semarang City, Central Java); SDN Padurungan
Tengah 02 (Semarang City, Central Java); SDN Sawahjoho 01 (Kabupaten Batang, Central Java); SDN Insan Amanah (Malang City, East Java); SDN Kademangan 01 (Blitar Regency, East Java); SDN Kademangan 05 (Blitar Regency, East Java); and SDN Kanigoro 03 (Blitar District, East Java).

3. Student management of elementary school on the island of Java which is below the average score far there are 9. Most come from West Java as much as 5 elementary school, same from Central Java 2 elementary and East Java 2 elementary school. Complete as follows: SDN Andir Kidul (City of Bandung, West Java); SDN Sejahtera 4 (Bandung, 
West Java); SDN Tegalkalong 1 (Sumedang District, West Java); SDN Pesanggrahan 1 (Sumedang District, West Java); SDN Gudang 1 (Sumedang District, West Java); SDN Tegalsari 02 (Batang Regency, Central Java); SDN Wonokerso 01 (Batang District, Central Java); SDN Pandanwangi 1 (Malang City, East Java); and SDN Purwantoro 1 (Malang City, East Java).

4. Based on provinces, the student management of elementary school in Java, the highest score up to the lowest is the province of East Java, Central Java, and West Java. Of West Java with a score of 96.83 included in the qualification is very good and is above the overall average score. Central Java with a score of 93.06 including excellent qualification, also above the overall average score. West Java with a score of 88.89 includes excellent qualification, but is below the overall average score. Thus, by province, the student management of elementary school in Java who have average scores above the overall score is the province of East Java and Central Java, while the province of West Java has a score value below the overall average.
5. Judging from the aspect / element of student's management, elementary school in Java get the successive score from highest to lowest that is: documenting evidence of student management activities, with scores above the overall average of 97.22 (very good); consideration of extracurricular activities, with a score above the overall average, 94.44 (very good); discipline of learners, with scores below average, 91.67 (very good); service of gifted learners, with scores below average, 91.67 (excellent); extracurricular activities, with scores below the overall average, i.e. 77.78 (good); and steps for admission of new learners (PPDB), with scores below the overall average, i.e. 25.00 (very low).

6. There are 2 aspects of student management that are above the overall average, and there are 4 aspects that scored below the average.

Data on the student management in elementary school of Java Island from the highest to lowest score recorded in Table 4.

Table 4

Data Description of Student Management in Elmentary School from Java Island Highest Score to Lowest

\begin{tabular}{|c|c|c|c|c|c|c|c|c|c|c|}
\hline No & Provinces & Distric / City & Name School & NAS & CA & CEA & SD & LTS & DSM & SM \\
\hline 1 & Central Jawa & Semarang City & SDN Kepunden & 1 & 4 & 4 & 4 & 4 & 4 & 100.00 \\
\hline 2 & Central Jawa & Semarang City & $\begin{array}{l}\text { SD Hj. Isriati } \\
\text { Baiturrah man }\end{array}$ & 1 & 4 & 4 & 4 & 4 & 4 & 100.00 \\
\hline 3 & Central Jawa & Semarang City & $\begin{array}{l}\text { SDN Pedurungan } \\
\text { Tengah } 02\end{array}$ & 1 & 4 & 4 & 4 & 4 & 4 & 100.00 \\
\hline 4 & East Java & Malang City & SD Insan Amanah & 1 & 4 & 4 & 4 & 4 & 4 & 100.00 \\
\hline 5 & East Java & Blitar District & SDN Kadema ngan 01 & 1 & 4 & 4 & 4 & 4 & 4 & 100.00 \\
\hline 6 & East Java & Blitar District & SDN Kadema ngan 05 & 1 & 4 & 4 & 4 & 4 & 4 & 100.00 \\
\hline 7 & Central Jawa & Batang District & SDN Sawahjoho 01 & 1 & 3 & 4 & 4 & 4 & 4 & 95.83 \\
\hline 8 & East Java & Blitar District & SDN Kanigoro 03 & 1 & 3 & 4 & 4 & 4 & 4 & 95.83 \\
\hline 9 & West Java & Bandung City & SDN Asmi & 1 & 4 & 4 & 4 & 3 & 4 & 95.83 \\
\hline 10 & Central Jawa & Batang District & SDN Tegalsari 02 & 1 & 3 & 4 & 3 & 4 & 4 & 91.67 \\
\hline 11 & West Java & Sumedang District & SDN Tegalkalong 1 & 1 & 3 & 4 & 4 & 3 & 4 & 91.67 \\
\hline 12 & West Java & Sumedang District & SDN Pasanggra han 1 & 1 & 3 & 4 & 4 & 4 & 4 & 91.67 \\
\hline 13 & East Java & Malang City & SDN Purwantoro 1 & 1 & 4 & 4 & 3 & 3 & 4 & 91.67 \\
\hline 14 & West Java & Bandung City & SDN Andir Kidul & 1 & 3 & 4 & 4 & 4 & 3 & 91.67 \\
\hline 15 & East Java & Malang City & SDN Pandan Wangi 1 & 1 & 3 & 4 & 4 & 3 & 3 & 87.50 \\
\hline 16 & West Java & Bandung City & SDN Sejahtera 4 & 1 & 2 & 4 & 3 & 4 & 4 & 87.50 \\
\hline 17 & West Java & Bandung City & SDN Gudang I & 1 & 3 & 3 & 3 & 3 & 3 & 75.00 \\
\hline 18 & Central Jawa & Batang District & SDN Wonokerso 01 & 1 & 2 & 3 & 3 & 3 & 4 & 70.83 \\
\hline \multicolumn{11}{|c|}{ Note: } \\
\hline \multicolumn{3}{|c|}{ New Admissions Steps } & : NAS & & & & & & & \\
\hline \multicolumn{3}{|c|}{ Extracurruculer Activity } & : CA & & & & & & & \\
\hline \multicolumn{3}{|c|}{ Consideration of Extracuricular Activities } & : CEA & & & & & & & \\
\hline \multicolumn{3}{|c|}{ Student Discipline } & : SD & & & & & & & \\
\hline \multicolumn{3}{|c|}{ Learners Talent Service } & : LTS & & & & & & & \\
\hline \multicolumn{3}{|c|}{ Ducumenting Students' Management } & : DSM & & & & & & & \\
\hline \multicolumn{3}{|c|}{ Student Management score } & : SM & & & & & & & \\
\hline
\end{tabular}

Based on Table 4, it can be concluded two research results, namely:

1. Student management of primary school in Java who get the highest score is $6 \mathrm{SD}$. Originally from Central Java, there were 3 SD and East Java 3 SD, and from Jabar was not available. The complete are: SDN Kepunden (Semarang City, Central Java); SDN Hj. Isriati Baiturrohman (Semarang City, Central Java); SDN Pedurungan Tengah 02 (Semarang City, Central Java); SDN Insan Amanah (Malang City, East Java); SDN Kademangan 01
(Blitar Regency, East Java); and SDN Kademangan 01 (Blitar Regency, East Java).

2. Student management of elementary school in Java Island with the lowest score 2 is SDN Gudang 1 (Bandung, West Java) with a score of 75.00 including good qualification, and SDN Wonokerto 01 (Kabupaten Batang, Central Java) with a score of 70.83 including good qualification. Both come from Jabar and Central Java. 
Data on the management of primary school elaborated in Table 5. students in Java Island by municipality and district are

Table 5

Data Description Student Management at Elementary School of Java Islan by City and District

\begin{tabular}{|c|c|c|c|c|c|c|c|c|c|c|}
\hline No & Provinces & Distric / City & Name School & NAS & CA & CEA & SD & LTS & DSM & SM \\
\hline 1 & Central Jawa & Semarang City & SDN Kepunden & 1 & 4 & 4 & 4 & 4 & 4 & 100.00 \\
\hline \multirow[t]{2}{*}{2} & Central Jawa & Semarang City & SD Hj. Isriati & & & & & & & \\
\hline & & & Baiturrahman & 1 & 4 & 4 & 4 & 4 & 4 & 100.00 \\
\hline \multirow[t]{2}{*}{3} & Central Jawa & Semarang City & SDN Pedurungan & & & & & & & \\
\hline & & & Tengah 02 & 1 & 4 & 4 & 4 & 4 & 4 & 100.00 \\
\hline 4 & East Java & Malang City & SD Insan Amanah & 1 & 4 & 4 & 4 & 4 & 4 & 100.00 \\
\hline 5 & West Java & Bandung City & SDN Asmi & 1 & 4 & 4 & 4 & 3 & 4 & 95.83 \\
\hline 6 & East Java & Malang City & SDN Purwantoro 1 & 1 & 4 & 4 & 3 & 3 & 4 & 91.67 \\
\hline 7 & West Java & Bandung City & SDN Andir Kidul & 1 & 3 & 4 & 4 & 4 & 3 & 91.67 \\
\hline 8 & East Java & Malang City & SDN Pandan Wangi 1 & 1 & 3 & 4 & 4 & 3 & 3 & 87.50 \\
\hline 9 & West Java & Bandung City & SDN Sejahtera 4 & 1 & 2 & 4 & 3 & 4 & 4 & 87.50 \\
\hline \multicolumn{3}{|c|}{ City Average } & & 25 & 88.87 & 100 & 94.44 & 91.67 & 94.44 & 94.90 \\
\hline 10 & West Java & Bandung City & SDN Gudang 1 & 1 & 3 & 3 & 3 & 3 & 3 & 75.00 \\
\hline 11 & East Java & Blitar District & SDN Kademangan 01 & 1 & 4 & 4 & 4 & 4 & 4 & 100.00 \\
\hline 12 & East Java & Blitar District & SDN Kademangan 05 & 1 & 4 & 4 & 4 & 4 & 4 & 100,00 \\
\hline 13 & Central Jawa & Batang District & SDN Sawahjoho 01 & 1 & 3 & 4 & 4 & 4 & 4 & 95.83 \\
\hline 14 & Jatim & Blitar District & SDN Kanigoro 03 & 1 & 3 & 4 & 4 & 4 & 4 & 95.83 \\
\hline 15 & Central Jawa & Batang District & SDN Tegalsari 02 & 1 & 3 & 4 & 3 & 4 & 4 & 91.67 \\
\hline 16 & West Java & Sumedang District & SDN Tegalkalong I & 1 & 3 & 4 & 4 & 3 & 4 & 91.67 \\
\hline 17 & West Java & Sumedang District & SDN Pasanggrahan I & 1 & 3 & 4 & 4 & 4 & 4 & 91.67 \\
\hline 18 & Central Jawa & Batang District & SDN Wonokerso 01 & 1 & 2 & 3 & 3 & 3 & 4 & 70.83 \\
\hline \multicolumn{3}{|c|}{ District Average } & & 25 & 77.78 & 94.44 & 91.67 & 91.67 & 97.22 & 90.28 \\
\hline
\end{tabular}

Note:

$\begin{array}{ll}\text { New Admissions Steps } & \text { : NAS } \\ \text { Extracurruculer Activity } & : \text { CA } \\ \text { Consideration of Extracuricular Activities } & : \text { CEA } \\ \text { Student Discipline } & : \text { SD } \\ \text { Learners Talent Service } & : \text { LTS } \\ \text { Ducumenting Students' Management } & : \text { DSM } \\ \text { Student Management score } & : \text { SM }\end{array}$

The conclusions obtained from Table 5 are 2 , namely:

1. Based on the districts and city of elementary school management on the island of Java, the results obtained that the score of SD in the city is higher than in the primary school $(94.90>90.28)$. Both are very high.

2. Student management in elementary school in Java Island has an average score above the overall score, whereas in district area it has average score below overall score.

One of the important findings in this study is that the management of elementary school students in Java is 92, 93 including in excellent qualifications. This implies the implementation of the student management indicators that like 6 aspects all on average in excellent qualifications. The six indicators include: (1) new student admission (PPDB); (2) discipline of learners; (3) gifted learners services; (4) extracurricular activities; (5) consideration of extracurricular activities; and (6) documenting evidence of student management activities.

A review of the scope of the student management in general, the results of this study also indicate the excellent implementation of all scope. The scope of student's management is generally stated by Rugaiyah \& Sismiati (2011) and Arikunto \& Yuliana (2008) stated that the student management is an activity of managing learners starting with new student acceptance, registration, selection, acceptance or placement. Once the learner is accepted, the next stage is to provide disciplinary coaching, activities that take place inside the school environment as well as outside the school. Activity of talent and interest development through extracurricular activities and other activities. Formal guidance is done until the students are declared graduated from school, the final stage is to establish a relationship with the alumni. So it can be concluded that the management of learners is the arrangement of all things related to learners in a school ranging from planning, acceptance of learners, coaching conducted during the students are in school, until the students complete education at school.

Starting from the opinion of Jump (2006) which gives the rational importance of developing the program of learners or learners with basic assumptions helps learners to develop namely: (1) each individual student has different and unique needs; (2) each learner has a different environment and is used for education; and (3) each learner has responsibility for his education; then the results of this study may take into account such assumptions. The results of this study is also relatively cheap rational from Allen (1986) which states the diversity of learners achievement of the success of learners, it is necessary the management of good learners for good education results as well. Allen also expressed the need for learners to have equal opportunity to get education and to develop each other's optimum potential, which varies among learners from each other.

Judging from the function of student management, the results of the study can also be understood to have fulfilled the management functions 
of learners. Student management function is a means for learners to develop themselves as optimally as possible, whether individual, social, aspirations, needs and other potential (Directorate of Primary Education, 2013). Other experts stated that the management function of the students in general is as a vehicle for learners to develop themselves as optimally as possible, whether with regard to aspects of their individuality, social aspect, aspiration aspect, and aspect of their needs and other potential aspects of the students (Imron, 1994).

The results of this study if associated with student management objectives, then relatively can achieve goals very well. The purpose of student management is to organize the activities of learners in order to support the teaching and learning process in schools in achieving the goals of the school and the optimal educational objectives (Directorate of Primary Education, 2013). Imron (2011) mentions the following objectives of the students' management specifically: (1) improving the knowledge, skills and psychomotor of learners; (2) channeling and developing the general ability (intelligence), talents and interests of learners; (3) channeling aspirations, expectations and meeting the needs of learners; and (4) with the fulfillment of all the above expected learners can achieve happiness and welfare of life that can further learn well and achieved their goals. Student management is the process of managing all matters relating to learners, school coaching starting from the planning of acceptance of learners, coaching during learners are in school, until the students educate students through the creation of an atmosphere conducive to the ongoing effective teaching and learning process (Mantja, 2007).

The steps admissions steps (PPDB) as a series of student management of elementary school in Java in this study showed scores below the overall average, i.e. 25.00, which means very low. This suggests that the whole range of new enrollment activities may not be well or poorly implemented in elementary schools in Java. Soetjipto and Kosasi (2009) stated that the acceptance of learners is the process of recording and servicing newly enrolled students after they have fulfilled the requirements set by the school. Acceptance of new learners so that students can receive learners in accordance with the capacity, facilities and faculty team and readiness of learners to study at targeted schools. According to Rugaiyah and Sismiati (2011) there are several things that must be considered in the acceptance of new learners, namely: the determination of new student acceptance committee, the provision of the format or biography of learners, preparation of the necessary tools and instruments and the policy provisions of the education office. The acceptance policy of these learners is usually done on the basis of the instructions given by the kabupaten / kota education office. Based on these two reviews, when compared with the results of the research, the steps in the theory have not been implemented properly.

Based on the results of this study it is also possible that the policy acceptance of new learners also have not or did not perform well. According to the Education and Training Manual of Kemdiknas
(Ministry of National Education) on Participatory Management (2007) and Concern (2011) that the operational policy of the acceptance of new learners, contains rules on the number of students who can be accepted in a school. Determination of the number of students, of course also based on the facts that exist in school according to conditional factors include; the capacity of new classes, criteria of acceptable learners, available budgets, existing infrastructure and facilities, available education personnel, number of students living in first grade, and so on. The operational policies of student acceptance also include a system of registration and selection or screening that will apply to learners. In addition, the acceptance policy of learners, also contains the time of registration, when started and when terminated. Furthermore, the acceptance policy of learners should also include personnel that will be involved in the registration, selection and acceptance of learners.

Based the field of student acceptance of the reception of the smell of many officials and acquaintances. For teachers and principals often ewuh pakewuh if ignore the deposit. Not to mention if the deposit is accompanied by the threat of loss of position or transfer to other places that are less interested teachers and principals. In the field also found the selection with the test read, write, and count at the level of elementary school. This is a relatively real and massive offense committed by a number of teachers and principals. Regulation of the Minister of Education and Culture of the Republic of Indonesia Number 17 of 2017 On the Acceptance of New Students at Kindergarten, Primary School, Junior High School, Senior High School, Vocational High School, or Other Form The equivalent regulate PPDB should, among others Article 11 Paragraph (1) as follows.

Selection of new learners of grade 1 (one) elementary or other equivalent form consider the criteria in the order of priority in accordance with the capacity based on the provisions of the study group as follows: (1) age as referred to in article 5 paragraph 1 ; and (2) distance of residence to the School in accordance with zoning provisions; in the selection of prospective new students of grade 1 (one) primary school or other similar forms as referred to in paragraph 1 there is no reading, writing and numeracy test.

Subsequent rules on the objectives are contained in Article 2, whereby the PPDB aims to ensure the acceptance of new learners in an objective, accountable, transparent, and non-discriminatory manner thereby promoting increased access to education services. The latest regulation on PPDB procedures that PPDB is implemented through online and offline mechanisms with respect to the educational calendar. Schools held by local governments implement PPDB in June to July each year. Schools held by local governments are required to publicly announce the implementation process and information of the PPDB, among others, on requirements, selection, and capacity based on study group requirements, fees, and acceptance of new learners through bulletin boards and other media. 
The results of this study resulted in the phenomenon that extracurricular activities with scores below the overall average, i.e. 77.78 were included in the qualification either. Based on these results, it is possible to develop students as in the Regulation of the Minister of National Education of the Republic of Indonesia Number 39 Year 2008 regarding Student Development can be achieved well. Student coaching goals: (1) developing the potential of learners optimally and integrated which includes talents, interests, and creativity; (2) to strengthen the personality of learners to realize the resilience of the school as an educational environment so as to avoid negative efforts and influences and contrary to educational objectives; (3) actualize the potential of learners in the achievement of superior achievement according to talent and interest; and (4) preparing learners to become citizens of morality, democracy, respect for human rights in order to realize civil society (civil society).

In Article 3 of the regulation, it is stated that: (1) student coaching is conducted through extracurricular and kokurikuler activities; and (2) the subjects of education shall include: (a) faith and devotion to god almighty; (b) noble character or noble character; (c) superior personality, nationality insight, and state defense; (d) academic, artistic, and / or sporting achievements according to talent and interest; (e) democracy, human rights, political education, the environment, sensitivity and social tolerance in the context of plural society; (f) creativity, skill, and entrepreneurship; ( $\mathrm{g}$ ) physical, health, and nutritional qualities based on a diversified source of nutrition; (h) literature and culture; (i) information and communication technology; and (j) communication in English.

In this Ministerial Regulation, what is meant by extracurricular activities is curricular activities conducted by learners outside the learning hours of intrakurikuler activities and kokurikuler activities, under the guidance and supervision of educational units. Extracurricular activities are held with the aim to develop the potential, talent, interest, ability, personality, cooperation, and independence of learners optimally in order to support the achievement of national education objectives. The education unit should meet the established rules, among others, in article 5(1) The Ministerial decree states that the educational unit is obliged to prepare an extracurricular activity program that is part of the school work plan. The extracurricular activities program includes: (1) rational and general objectives; (2) description of any extracurricular activities; (3) management; (4) funding; and (5) evaluation. Programs of extracurricular activities are socialized to learners and parents / guardians at the beginning of each school year.

The consideration of curricular activities covering the availability of educators, curriculum/program, the adequacy of facilities and infrastructure/tools/facilities/materials, and local environmental conditions/local culture, found in this study included in excellent qualifications (94.44). Implementation of such considerations in the field, in the future needs to be adjusted to the government's mandate as stipulated in the Regulation of the Minister of National Education of the Republic of Indonesia Number 39 Year 2008 regarding Student Development Article 6 that the implementation of extracurricular activities program consider the use of shared resources available in school cluster or school cluster. The use of shared resources is facilitated by the provincial or district / municipal governments in accordance with their respective authorities.

Jump (2006) provides a rationale for the importance of developing a learner program that is basic assumption helps learners to develop namely: (1) each learner individually has different needs and unique; (2) each learner has a different environment and is used for education; and (3) each learner has responsibility for his / her education. Based on the study of this theory, the field may have met the considerations as the theory sounds. Similarly, another rational review of the importance of the guidance of learners proposed by Allen (1986) which states that learners come from diverse backgrounds, some with a harsh cultural background or racist background, there are conflicts of various causes, while others do not experience it. All that affect the success of learners in education. It is necessary to arrange learners in order to have equal opportunity to obtain education and can develop optimally their potential, which varies among learners from each other. On the other hand, the field needs to be corrected also on the reasons expressed by both experts, whether it has been implemented or not.

The results of the study showed that students' discipline score is 91.67 is in excellent qualification. Student coaching is the provision of services to learners in an educational institution, both within and outside of class hours, in order to create conditions and make learners aware of their learning tasks (Soetjipto \& Kosasi, 2009). In this case there are some things related to the study of student coaching: (1) disciplining learners; (2) guidance of intrakurikuler activities; and (3) the development of talent and interest through extracurricular activities. Regulation of the Minister of National Education of the Republic of Indonesia Number 39 Year 2008 regarding Student Development is stated that to develop the potential of learners in accordance with the function and purpose of national education, namely learners who believe and fear Allah Almighty, have noble character, healthy, knowledgeable, proficient, creative, independent, and become a democratic and responsible citizen, it is necessary to coach education in systematic and sustainable.

Related to disciplinary coaching of learners, discipline is very important for learners, therefore, must be instilled continuously to learners. If discipline is implanted continuously then the discipline will become a habit for learners. Schaefer (1986) suggests that: the core of the discipline is teaching, or for someone who follows the teachings of a leader. According to Harrys (1985) discipline refers fundamentally to the principle that each organism learns in some degree to control it self so as to conform to the forces around it with which it has experiences. There are several elements of understanding in it, 
among others: (1) contains the moral governing the order of life; (2) the development of the ego with all the intrinsic problems that require a person to make choices; (3) the growth of power to provide answers to every rule submitted; and (4) acceptance of external authority that helps one to shape the capabilities and limitations of life (Imron, 2011). The discipline of learners is an orderly and orderly condition that the learners have in school, without any violation of the violations that are harmful either directly or indirectly to the students themselves and to the school as a whole.

Further Imron (2011) argues that there are three kinds of discipline, the first discipline built on authoritarian concept, according to this concept learners in school is said to have high discipline when want to sit quietly while paying attention to the teacher's description while teaching. Learners are required to agree only on what the teacher wants, and should not argue. Both disciplines are built on the concept of permissive according to this concept learners should be given the widest possible freedom in the classroom and school. The average score of gifted learners is 91.67 in excellent qualifications. This means that the services of gifted elementary school students in Java, including peer tutors, Olympic MIPA, and sports achievements have been very well executed.

Regulation of the Minister of National Education No. 34 of 2006 on the Establishment of Achievement of Students with the Potential of Intelligence and / or special talent consider that learners who have the potential of intelligence and / or special talents have a great opportunity to bring the name of nation, state, region and unit education, and therefore a coaching system is needed to actualize its potential and talent. Judging from this regulation, then in the field has complied with these considerations. So also in terms of the purpose of coaching achievement of learners in the regulation is relatively achievable. The purpose of guiding the achievement of learners who have the potential of intelligence and / or special talent is to: (1) obtain learners who achieve peak performance in the field of science and technology, aesthetics, and / or sports, at the level of educational unit, district / city, provincial, national, and international; (2) motivate as many students as possible to compete to achieve optimal achievement in accordance with their potential and strength so that the coaching is not only able to produce learners with peak performance, but also improve the average achievement of learners; and (3) developing an appreciative society culture toward achievement in the field of education.

Judging from the scope of the activities of the students who carried out elementary school development in Java, need to be adjusted with the scope of coaching as in the applicable laws and regulations. Guidance on the achievement of learners who have the potential of intelligence and / or special talent include: (1) selection; (2) continuous coaching; and (3) awarding. Documenting evidence of student management activities, with a score above the overall average of 97.22 (very good). This is likely because schools have generally followed accreditation and filled out Dapodik. In both activities, evidence of activities must be complete. The completeness of the evidence of activities in this research that has been well implemented includes 23 books. Detailed documentation of evidence of student management activities in addition to the fact that the school has applied for accreditation, has filled out Dapodik, possibly also due to regular monitoring and evaluation from various authorities, continuous coaching, and strong willingness of all educators and educators to make their schools become better and more effective schools.

\section{CONCLUSION}

Based on the results of research, it can be concluded some things as follows:

1. Student management of elementary school in Java is included in the excellent qualification.

2. Student management of elementary school on the island of Java which is above the overall average score is 9. At least from West Java as much as 1 elementary school, while from Central Java 4 elementary and East Java 4 elementary school.

3. Student management of elementary school on the island of Java, which is below the overall average score is 9. Most come from West Java as much as 5 elementary schools, the same from Central Java 2 elementary and East Java 2 elementary school.

4. Based on the province, the student management of elementary school in Java, the highest score up to the lowest is the province of East Java, Central Java, and West Java. Those with an average score above the overall score are the provinces of East Java and Central Java, while the province of West Java has a score value below the overall average.

5. Viewed from the aspect / element of student's management, elementary school in Java get the successive score from highest to lowest i.e.: documenting evidence of student management activities, with scores above the overall average, and including excellent qualifications; consideration of extracurricular activities, with scores above the overall average, and includes excellent qualifications; discipline of learners, with scores below the overall average, and includes excellent qualifications; service of gifted learners, with scores below the overall average, and includes excellent qualifications; extracurricular activities, with scores below the overall average, and include good qualifications; and step-by-step acceptance of new learners (PPDB), with scores below the overall average, and includes very low qualifications.

6. There are 2 aspects of student management that score above the overall average, and there are 4 aspects that score below the overall average.

7. Student management of elementary school in Java who get the highest score of 100 there are 6 SD. From Central Java, there were 3 elementary schools and 3 East Java, and from West Java did not exist.

8. Student management of elementary school in Java with the lowest score is SDN Gudang 1 (Bandung, West Java) including good 
qualification, and SDN Wonokerto 01 (Batang District, Central Java) including good qualification. Both come from West Java and Central Java.

9. Based on the districts and municipalities of elementary school management on the island of Java, the results obtained that the score of SD in the city is higher than the primary school in the district. Both are very high.

10. Student management in Java's urban elementary school has an average score above the overall score, whereas in district areas it has an average score below the overall score.

\section{REFERENCES}

[1] Allen, E. I. 1986. Developmental Therapy: Theory into Practice. San Francisco: Jossey Bass.

[2] Arikunto, S. 1986. Classroom Management and Learners: An Evaluative Approach. Jakarta: Rajawali.

[3] Directorate of Primary Education. 2012. Guidance on School Based Management (SBM) Guidance in Elementary School (Book I). Jakarta: Directorate of Primary Education, Ministry of Education and Culture.

[4] Directorate of Primary Education. 2013. Pattern of Development and Development of School Based Management in Elementary School. Jakarta: Directorate of Primary Education, Ministry of Education and Culture.

[5] Imron, A. 2011. Management of School-Based Learners. Jakarta: Earth Literacy.

[6] Jump, U. 2006. Student Development Theory. Texas: University of Texas.

[7] Ministry of Education and Culture. 2014. Regulation of the Minister of Education and Culture of the Republic of Indonesia No. 62 of 2014 on Extracurricular Activities in Basic Education and Secondary Education. Jakarta: Ministry of Education and Culture.

[8] Ministry of Education and Culture. 2017. Regulation of the Minister of Education and Culture of the Republic of Indonesia Number 17 of 2017 on the Acceptance of New Students in Kindergarten, Primary School, Junior High School, Senior High School, Vocational High School, or Other Form of Equivalent. Jakarta: Ministry of Education and Culture.

[9] The Ministry of National Education. 2006. Regulation of the Minister of National Education of the Republic of Indonesia Number 34 Year 2006 concerning the Development of Achievement of Students with Potential of Intelligence and / or Special Talent. Jakarta: Ministry of National Education.

[10] The Ministry of National Education. 2007. Educational and Training Guidelines on Possessed Education Management. Jakarta: Ministry of National Education.

[11] The Ministry of National Education. 2008. Regulation of the Minister of National Education of the Republic of Indonesia Number 39 Year 2008 concerning the Development of Educational Participation. Jakarta: Ministry of National Education. 2008.

[12] Knezevich, S. J. 1984. Administration of Public Education. A Sourcebook for the Leadership and Management of Education Institutions. New York: Harper \& Row, Publishers.

[13] Mantja, W. 2007. Professionalization of Teachers, Education Management and Teaching Supervision. Malang: Elang Mas.

[14] Mulyasa, E. 2004. School Based Management. Bandung: PT Remaja Rosdakarya.
[15] Rugaiyah, \& Sismiati, A. 2011. Profession of Education. Jakarta: Ghalia Indonesia

[16] Sahertian, P. A. 1985. Education Administration Dimension. Surabaya: Usaha Nasional.

[17] State Secretariat Republic of Indonesia. 2003. Law Number 20 Year 2003 on National Education System. Jakarta: State Secretariat, Republic of Indonesia.

[18] State Secretariat RI. 2013. Government Regulation No. 32 of 2013 on Amendment to Government Regulation Number 19 Year 2005 on National Education Standards. Jakarta: State Secretariat, Republic of Indonesia.

[19] Soetjipto, \& Kosasi, R. 2009. Teacher Profession. Jakarta: Rineka Cipta. 